\title{
Quantitation of mRNA Species by RT-PCR on Total mRNA Population
}

\author{
Samar Hamoui, ${ }^{1}$ Jean-Pierre Benedetto, Maurice Garret, and Jacques Bonnet ${ }^{2}$
}

Institut de Biochimie et de Génétique Cellulaires, 33077 Bordeaux CEDEX, France

\begin{abstract}
PCR is commonly used for mRNA quantitation. Previously described procedures are applied to one or a few specific mRNA sequences. We show here that methods used for amplifying heterogeneous CDNA populations can be applied to the quantitation of many mRNA species. This quantitation is achieved by dot blotting and hybridization with the corresponding probes after amplifying a bulk mRNA population. Only a single, two-round-amplification assay is required for quantitation of a whole set of mRNA species. The proportionality of input molecules to output signal was shown by performing a series of control experiments. We applied this technique to measure the relative variations of the MBP, Po, and MAG mRNA sequences in the normal trembler mouse model. The results were consistent with previously described Northern blot data. This quantitative PCR method provides a rapid and reliable way to quantify relative amounts of $m$ RNA species in small amounts of total RNA by using internal controls.
\end{abstract}

들 stimation of the amount of one or several mRNA species is a common way to monitor responses of biological systems to environmental stimuli or changes in develomental programs. The classic RNA hybridization technique has the disadvantage of requiring a considerable amount of mRNA (at least $10^{5}-10^{6}$ specific molecules per sample). With reverse transcription polymerase chain reaction (RT-PCR) the detection threshold has been lowered at least 1000 -fold. Various protocols using PCR for quantitating specific RNA species have been developed in the last few years. ${ }^{(1-13)}$ Reasonably good results have been obtained when an RNA molecule of known concentration is added to the sample and used as a standard and when the reaction is monitored during its exponential phase. ${ }^{(1,2,12)}$ Alternative quantitative procedures involving reactions that have been driven to the plateau have been also developed. ${ }^{(9,10,13)}$ However, these methods have some drawbacks. First, preliminary calibration analysis has to be carried out for each individual template. Second, such procedures allow one analysis and therefore give only one answer per PCR assay for the sample under study. Alternatively, amplification of complex DNA or cDNA mixtures have already been described ${ }^{(14-17)}$ for the constitution of DNA and cDNA libraries. Here, we show that such amplification techniques can be adapted to a quantitation end. Our strategy is outlined in Figure 1. First, a double-stranded cDNA population is synthesized from the RNA population to be studied. Second, a specially designed linker-adapter is bluntend ligated to this cDNA; third, the population is amplified in two successive rounds of 20-cycle PCR; fourth, aliquots of the amplification products are taken during the exponential phase of the second PCR round, dot-blotted, and hybridized with different specific probes. Finally, hybridization signals are plotted on a semi-log scale against the number of cycles, and quantitation of a given mRNA species is obtained by extrapolating to zero cycle. This provides an easy, accurate, and reproducible relative quantitation. This was shown explicitly by measuring expression levels of several mRNAs in the Trembler mouse model.

\section{MATERIALS AND METHODS}

\section{Animals}

Male Wistar rats weighing $350 \pm 25$ grams were used. Brains were removed rapidly on ice and cortices were isolated for RNA extraction. Normal and heterozygous 8-day old trembler mice (strain B6-CBA) were bred locally and used in the experiments. After cervical rupture, sciatic nerves were isolated for RNA extraction.

\section{RNA and CDNA Preparation}

RNAs were purified by the method of Chirgwin et al. ${ }^{(18)}$ Total RNA from brain $(2 \mu \mathrm{g})$ or the whole preparation from a single mouse sciatic nerve, $(\sim 1 \mu \mathrm{g})$ was reverse transcribed using a cDNA synthesis kit (Amersham). Reverse transcription was initiated by a 17-nucleotide oligo(dT), and its efficiency was estimated by measuring $\left[\alpha-{ }^{32} \mathrm{P}\right] \mathrm{dCTP}$ incorporation. The specific activity of $\left[\alpha-{ }^{32} \mathrm{P}\right] \mathrm{dCTP}$ was kept low so as to not interfere with the subsequent measurements. Amounts of 8 to $10 \mathrm{ng}$ of cDNA were usually obtained when starting with $1 \mu \mathrm{g}$ of total RNA. The cDNA was then purified on a
'Present address: Human Morphology Department Faculty of Medicine, American University of Beirut, Beirut, Lebanon. 


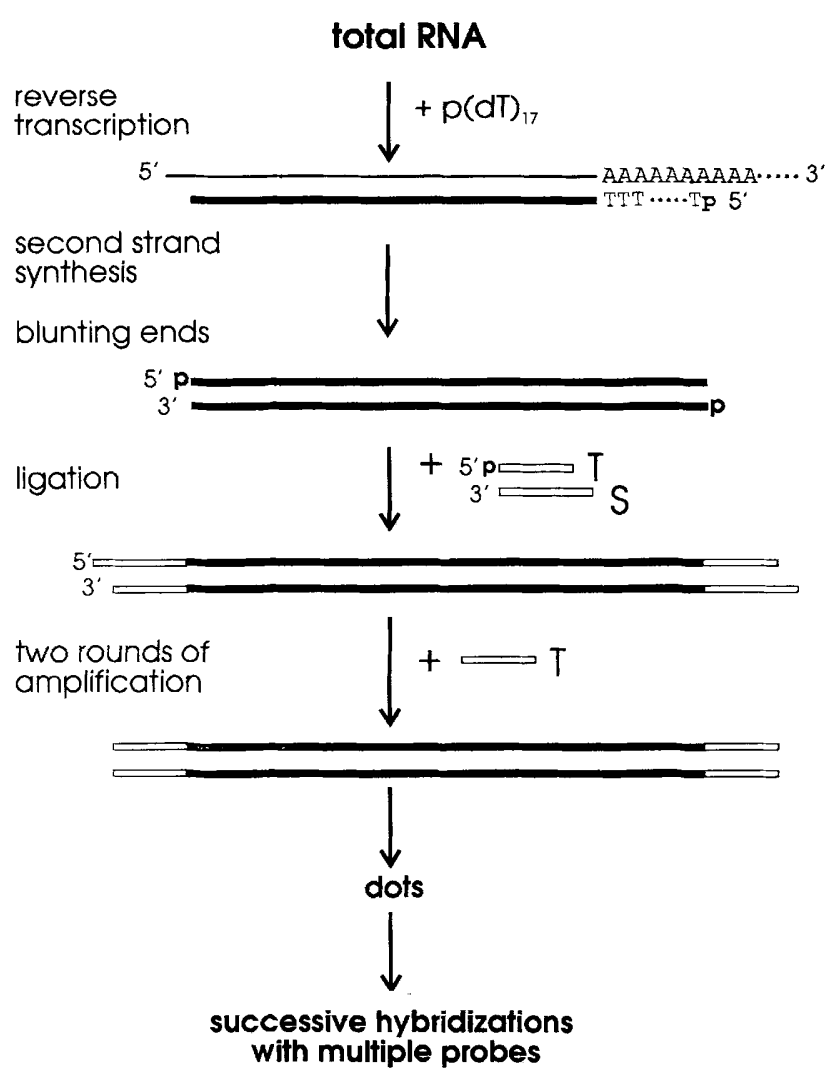

FICURE 1 Strategy for mRNA quantitation. (Details are provided in the text.)

spin G50 column (Boehringer Mannheim).

\section{Oligonucleotides and Linker}

Oligonucleotides S (20-nucleotide) and $\mathrm{T}$ (17-nucleotide) were synthesized on an Applied Biosystems 381A DNA automated synthesizer (IBGC/CNRSBordeaux) and purified on a Cytolab column. The oligonucleotide $T$ was phosphorylated prior to its annealing to oligonucleotide $\mathrm{S}$. The linker $\mathrm{S} / \mathrm{T}$ was used for ligation and the oligonucleotide $S$ for amplification. Oligonucleotide and linker are the following: $S$, 5'-GAGATATTAGAATTCTACTC-3'; T, 5'pGAGTAGAATTCTAATAT- $3^{\prime}$; and $S / T, 5^{\prime}-$ pGAGTAGAATTCTAATAT-3' and $3^{\prime}$-CTCATATTAAGATTATAGAG-5'.

\section{CDNA Ligation to S/T Linker}

cDNA ligation was performed in a $10-\mu l$ mixture containing 2.5 units of T4 DNA ligase (Pharmacia), $10 \mathrm{~mm}$ Tris-acetate, $10 \mathrm{~mm}$ magnesium acetate, $50 \mathrm{~mm}$ potassium acetate, $1 \mathrm{mM}$ ATP, $1 \mathrm{~mm} \mathrm{~S} / \mathrm{T}$ linker, and 4 ng of cDNA.

\section{PCR Amplification}

The standard amplification mixture contained $10 \mathrm{U} / \mathrm{ml}$ of Taq polymerase (Perkin-Elmer Cetus), $50 \mathrm{~mm} \mathrm{KCl,} 10 \mathrm{~mm}$ Tris- $\mathrm{HCl}$, (pH 8.3), $3 \mathrm{~mm} \mathrm{MgCl}, 200 \mu \mathrm{M}$ $\mathrm{dNTP}, 0.5 \mu \mathrm{M}$ of the $\mathrm{S}$ primer, $2 \mu \mathrm{Ci} / \mathrm{ml}$ of $\left[\gamma^{-32} \mathrm{P}\right] \mathrm{ATP}$ (included for pipetting and aliquoting normalization), and $4 \mathrm{ng}$ of cDNA. The amplification mixture was overlaid with $50 \mu$ l of mineral oil (Pharmacia). Amplification was usually achieved by two consecutive rounds. The first round was carried out in a 50- $\mu \mathrm{l}$ reaction for 20 cycles, and the second round was performed after adding $1 \mu l$ of the first-round amplification reaction to a fresh $100-\mu$ l reaction mixture for an additional 4-20 cycles. The two rounds of amplification started with a 5-min incubation at $95^{\circ} \mathrm{C}$ and consisted of sequential cycles (usually 20) of denaturation for $1 \mathrm{~min}$ at $95^{\circ} \mathrm{C}$, annealing for $30 \mathrm{sec}$ at $42^{\circ} \mathrm{C}$, and extension for $1 \mathrm{~min}$ at $72^{\circ} \mathrm{C}$ on a Biometra Trio-thermoblock PCR automated apparatus.

For the model system, known amounts of a 620 -bp fragment of the Podospora anserina het-s gene were added to the ligated cDNA at the first round.

\section{Preparation of the $P$. anserina DNA}

A double digestion by BamHI and KpnI of Bluescript II containing $2601 \mathrm{bp}$ of the $P$. anserina het-s gene ${ }^{(19)}$ generated a 620 bp fragment. After electrophoresis on low-melting Seaplaque GTG agarose (FMC), this 620-bp fragment was purified and then ligated to the $S / T$ linker and PCR amplified for 20 cycles. The amount of this fragment was estimated by running a last PCR cycle in the presence of $2 \mu \mathrm{Ci}$ of $\left[\alpha^{-{ }^{32}} \mathrm{P}\right] \mathrm{dCTP}$.

\section{Amplification Analysis of the Amplified CDNA}

After $5 \mathrm{~min}$ of denaturation at $95^{\circ} \mathrm{C}$, the amplified products were dot blotted, and hybridized with different specific probes. Probes were labeled with $\left[\alpha-{ }^{32} \mathrm{P}\right] \mathrm{dCTP}$ by random primed synthesis (Megaprime kit, Amersham). Final washing of the filters was performed at $65^{\circ} \mathrm{C}$ in $0.1 \%$ (mass/volume) SDS; $0.1 \times$ SSPE $\left(0.15 \mathrm{M} \mathrm{NaCl}, 10 \mathrm{~mm} \mathrm{NaH} \mathrm{PO}_{4}, 1\right.$ mM EDTA at $\mathrm{pH}$ 7.4) for $1 \mathrm{hr}$.

\section{Quantitation}

Quantitation of the hybridization signals was performed by autoradiograph densitometry or by Cerenkov counting. Autoradiographic exposure of filters to Amersham Hyperfilm MP was done for variable durations at $-70^{\circ} \mathrm{C}$, with a CGR micron R/S intensifying screen. Appropriate exposures (in the linear range of the film) were scanned using image analysis software (Samba 2005, Alcatel, TITN, or NIH Image). For the Cerenkov counting, the dots were cut out and counted by liquid scintillation.

\section{cDNA Probes}

Hamster $\beta$-actin, $P$. anserina het-s, mouse MBP (myelin basic protein), rat Po (major protein of peripheral nervous system), and MAG (myelin-associated glycoprotein) clones were gifts, respectively, from P. Chambon (Strasbourg, France), J. Bégueret (Bordeaux, France) Dr. A.R. Lazzarini (National Institutes of Health, Bethesda), Dr. G. Lemke (Columbia University, NY) and Dr. J.L. Salzer ${ }^{(20)}$. Human glyceraldehyde-3 phosphate dehydrogenase (G3PDH)-purified cDNA probe was purchased by Clontech. 


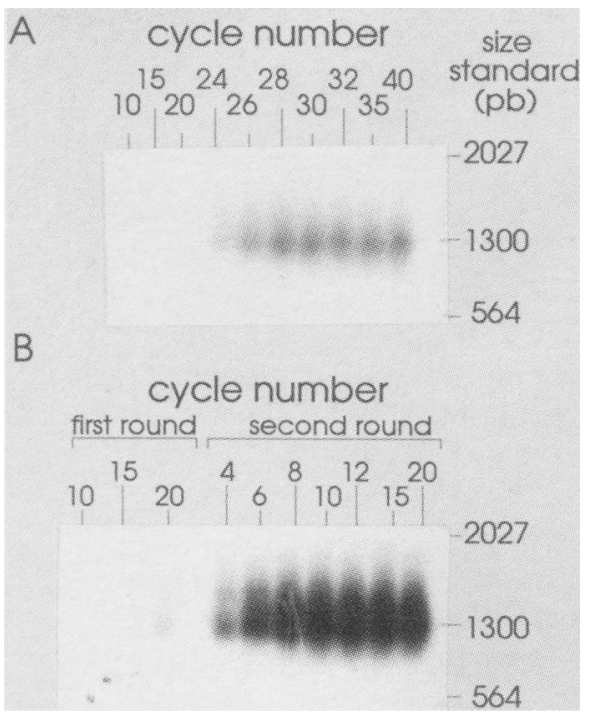

FIGURE 2 Amplification yields from one or two rounds PCR. Double-stranded cDNA obtained from $2 \mu \mathrm{g}$ of total cerebral cortex rat RNA was ligated to the $\mathrm{S} / \mathrm{T}$ linker. Amplification was performed on $4 \mathrm{ng}$ of cDNA. $(A) \mathrm{Am}$ plification was performed for one round of 40 cycles. Aliquots were removed as indicated, analyzed by gel electrophoresis on $1 \%$ agarose, transferred to a Hybond $\mathrm{N}$ membrane (Amersham), and hybridized with a G3PDH probe labeled with $\left[\alpha{ }^{32} P\right]$ dCTP. (B) Amplification was performed for two rounds of PCR ( 20 cycles each). Aliquots were removed as indicated and were processed as for $A$.

\section{RESULTS}

\section{Amplification Design}

Our objective was to amplify the total mRNA population of given samples and measure the relative quantity of one or several mRNA species by hybridization with specific probes. We chose the amplification protocol described previously. ${ }^{(14,15)}$ After oligo(dT)-primed reverse transcription, a common end sequence was added to the heterogeneous cDNA molecules through bluntend ligation of the specially designed linker ( $\mathrm{S} / \mathrm{T})$ (see Materials and Methods; Oligonucleotides and Linker). The asymmetric ends of this linker ensure directional ligation to the target cDNA population. This permits one strand of the (S/ T) linker (oligonucleotide $S$ ) to be used as a primer in the subsequent enzymatic amplification (see Fig. 1).

To obtain high amounts of PCR products, the cDNA amplification procedure was performed by two consecutive rounds, usually 20 cycles for the first round and 4-25 cycles for the second.
Figure 2 shows PCR amplification kinetics obtained with $4 \mathrm{ng}$ of rat normal cerebral cortex cDNA. In Figure 2A, PCR was achieved wih a single round of 40 cycles. In B, PCR was performed, with two rounds of PCR. After electrophoresis on a $1 \%$ agarose gel, the amplified products were transferred and hybridized with a G3PDH probe. Figure 2 shows that PCR performed with two rounds of PCR gives a much better yield of amplified products.

\section{Coamplification and Quantitation With the $P$. anserina Fragment}

To test the usefulness of such an approach for mRNA quantitation, we first used our RT-PCR assay on a model system. We prepared a series of samples by adding known amounts of a 620-bp fragment of the $P$. anserina het-s gene to the same amount of brain cDNA (the $P$. an- serina gene does not cross-hybridize with rat cDNA extracted from the cortex; data not shown). Blunt-ending and S/T linker ligation of the rat $\mathrm{CDNA}$ and of the $P$. anserina sequence were done under the same conditions as those for CDNA.

Amounts of 10, 100, and $1000 \mathrm{pg}$ (Fig. 3A) and 1, 3, 10, and $30 \mathrm{pg}$ (Fig. 3C) of the $P$. anserina fragment were added to the rat cDNA and coamplified as described in Figure 3 . Kinetics were monitored in the second round in the presence of $\left[\gamma_{-}{ }^{32} \mathrm{P}\right] \mathrm{ATP}$. (This radionucleotide cannot be incorporated to the PCR product and is so used to normalize for DNA pipetting and dotting between the different stop points of the kinetics.) Aliquots of the amplified products were removed every two cycles and spotted onto membrane for hybridization. After hybridization of the 620 -bp $P$. anserina probe, the dots were cut out and counted by liquid scintillation for their radioac-
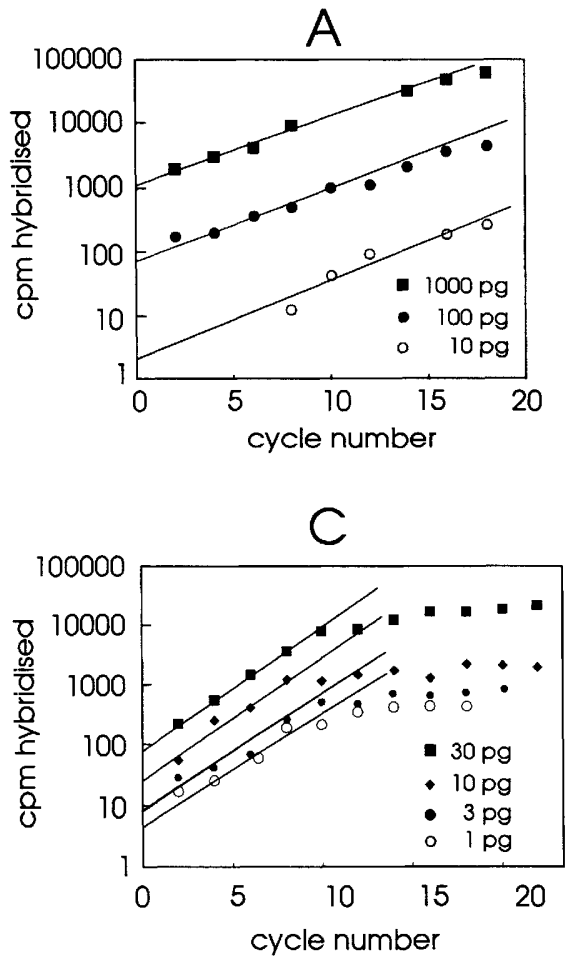
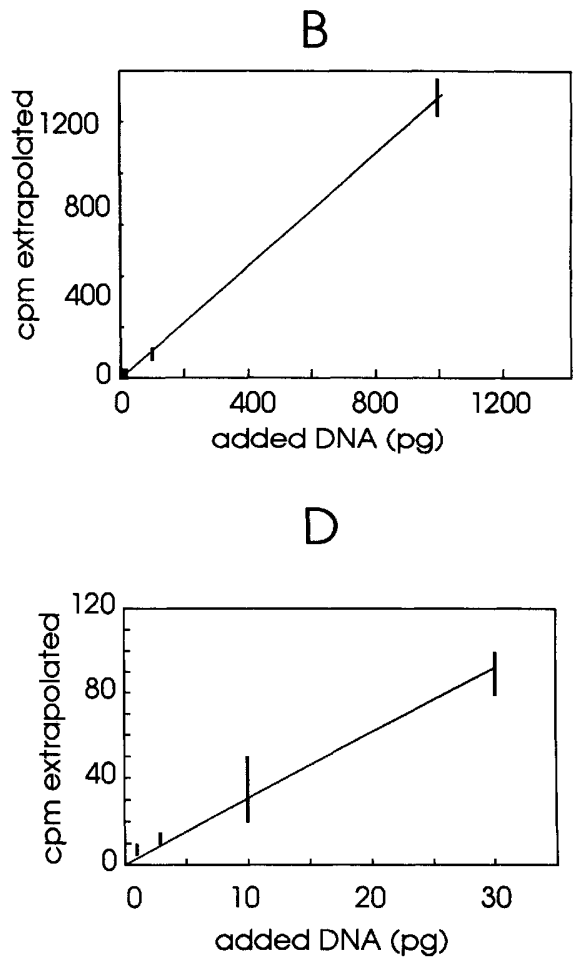

FIGURE 3 Quantitation assay with exogenous DNA. A 620-bp P. anserina fragment was ligated to the S/T linker and amplified as described in Materials and Methods (Preparation of the $P$. anserina DNA). Appropriate dilutions were added to $4 \mathrm{ng}$ of S/T linker-ligated cortex CDNA. The amounts of $P$. anserina fragment in each amplification mixture are as indicated. Two rounds of amplification were performed. Aliquots were removed, dotted on Hybond $\mathrm{N}$ membrane (Amersham), and probed with $\left[\alpha{ }^{32} \mathrm{P}\right] \mathrm{dCTP}$-labeled $P$. anserina sequence. After hybridization and washing, dots were cut out and counted by liquid scintillation. After correcting for pipetting and dotting variability (see Materials and Methods), results were plotted vs. cycle number on a semi-log scale $(A, C)$. Extrapolations to cycle 0 were plotted vs. the amount of $P$. anserina DNA added, on a linear scale $(B, D)$. Vertical bars were used to take into account the different possible extrapolation values. 

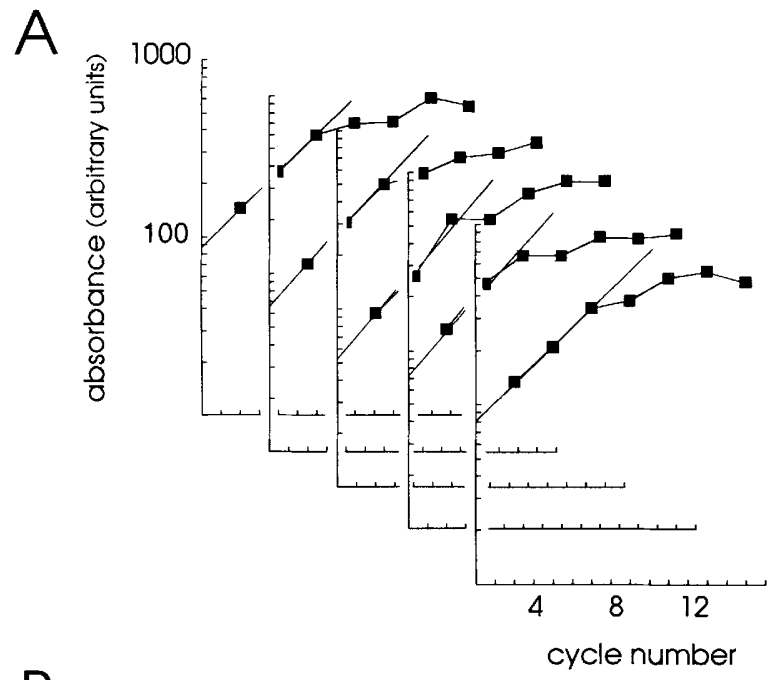

$\mathrm{B}$

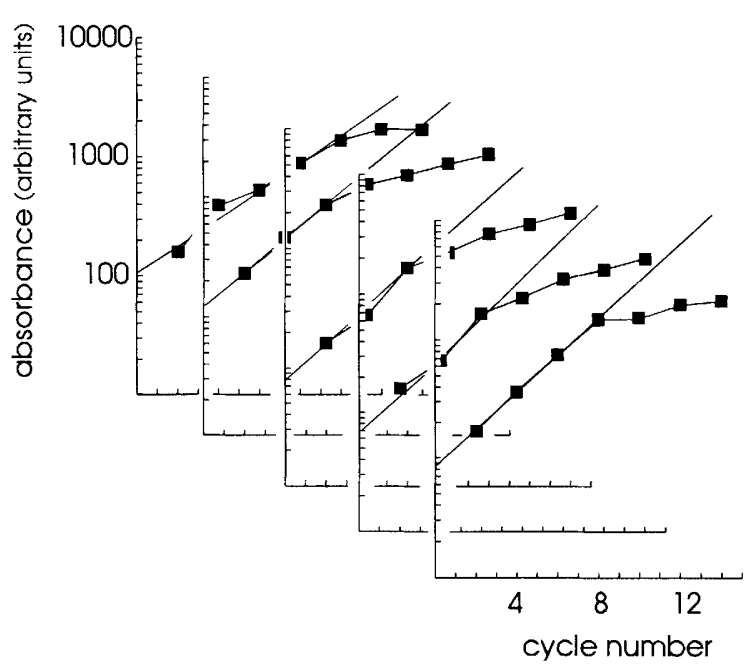

FIGURE 4 Reproducibility. Five parallel amplification kinetics with $1 \mathrm{pg}$ of the $P$. anserina sequence added to $4 \mathrm{ng}$ of rat CDNA were carried out as reported in Fig. 3. (A) PCR products were probed with G3PDH; $(B)$ PCR products were probed with $P$. anserina sequence.

tivity content. A control dot from a DNAfree region was also counted, and the counts were subtracted as a background. The corrected values were plotted on a semi-log scale (Fig. 3A,C). Figure 3, B and $D$, shows that in the ranges used here, there is a proportional relationship between these values and the initial DNA quantity.

In Figure 3, the kinetics reached a plateau after 10 cycles with $1-10 \mathrm{pg}$ of the $P$. anserina fragment but seems to be in the linear range after 15 cycles for $10-1000$ pg of fragment. This is as expected, because (1) even $1000 \mathrm{pg}$ is only a small quantity $(\sim 0.025 \%)$ of the cDNA to be amplified, and (2) the amplifications with $1-30 \mathrm{pg}$ and $10-1000 \mathrm{pg}$, respectively, have been run in two different experiments with two different batches of Taq polymerase.
A more complete control might have to begin with increasing amounts of a specific RNA molecule. However, we wanted to focus our investigation on the essential amplification step to show that for a given sequence, the amount of amplified products was proportional to the starting amounts.

\section{Reproducibility}

The reproducibility of the procedure mainly depends on the reverse transcription and PCR steps. Because the reproducibility of the former step is widely established we focused our attention on the latter step. The efficiency of PCR is affected by variables such as incubation times, reaction temperatures, and substrate concentrations. A variation in the efficiency of PCR between individual tubes in an experiment would lead to unequal amplifications from tube to tube, thus making quantitation impossible. To check tube-to-tube uniformity, we performed a coamplification series similar to that reported above. Five replicate samples containing $1 \mathrm{pg}$ of the $P$. anserina sequence and $4 \mathrm{ng}$ of brain cDNA (see Fig. 3) were amplified, and aliquots were dotted and hybridized first to $P$. anserina and then to G3PDH probes. Curves presented in Figure 4 show that similar amplification efficiencies were obtained for both G3PDH (Fig. 4A) and $P$. anserina probes (Fig. 4B). When the five samples of a given sequence were compared, the standard variation among the five extrapolated values was $\leqslant 16.5 \%$ (Fig. 4). Thus, the reproducibility of the procedure seems to be reasonable.

\section{Quantitation of Several mRNA Sequences in Normal and Trembler Mice}

We then used this procedure to measure the expression levels of three mRNAs species in the well-characterized trembler mouse model. The trembler mouse suffers from a dominantly inherited autosomal mutation affecting the Schwann cell activities; this results in an abnormal myelinization of the peripheral nervous system. ${ }^{(21-23)}$ Northern blot analyses have shown previously that the steady-state levels of mRNAs encoding myelin-specific proteins in normal and trembler mice are affected to various extents. ${ }^{(24-25)}$

Here, we wanted to check whether the relative level of expression of mRNA encoding Po, MBP, and MAG determined by our measurements could be correlated with the results of previous Northern analyses. Total RNA was extracted from a single sciatic nerve of 8-day-old normal or trembler mice. The two RNA samples ( $\cong 1 \mu \mathrm{g}$ each) were processed as described in Materials and Methods. The dotted PCR products were then hybridized successively with MBP, Po, MAG, and G3PDH probes. Quantitation was achieved by densitometry of the dot blots (Figs. 5 and 6) A ubiquitous mRNA probe, the human G3PDH corresponding to a key gene in glycolysis, was used as an internal control to normalize for errors in RNA measurements and variability in pipetting and blotting. This mRNA is believed to have constant expression in most tissues and was also 

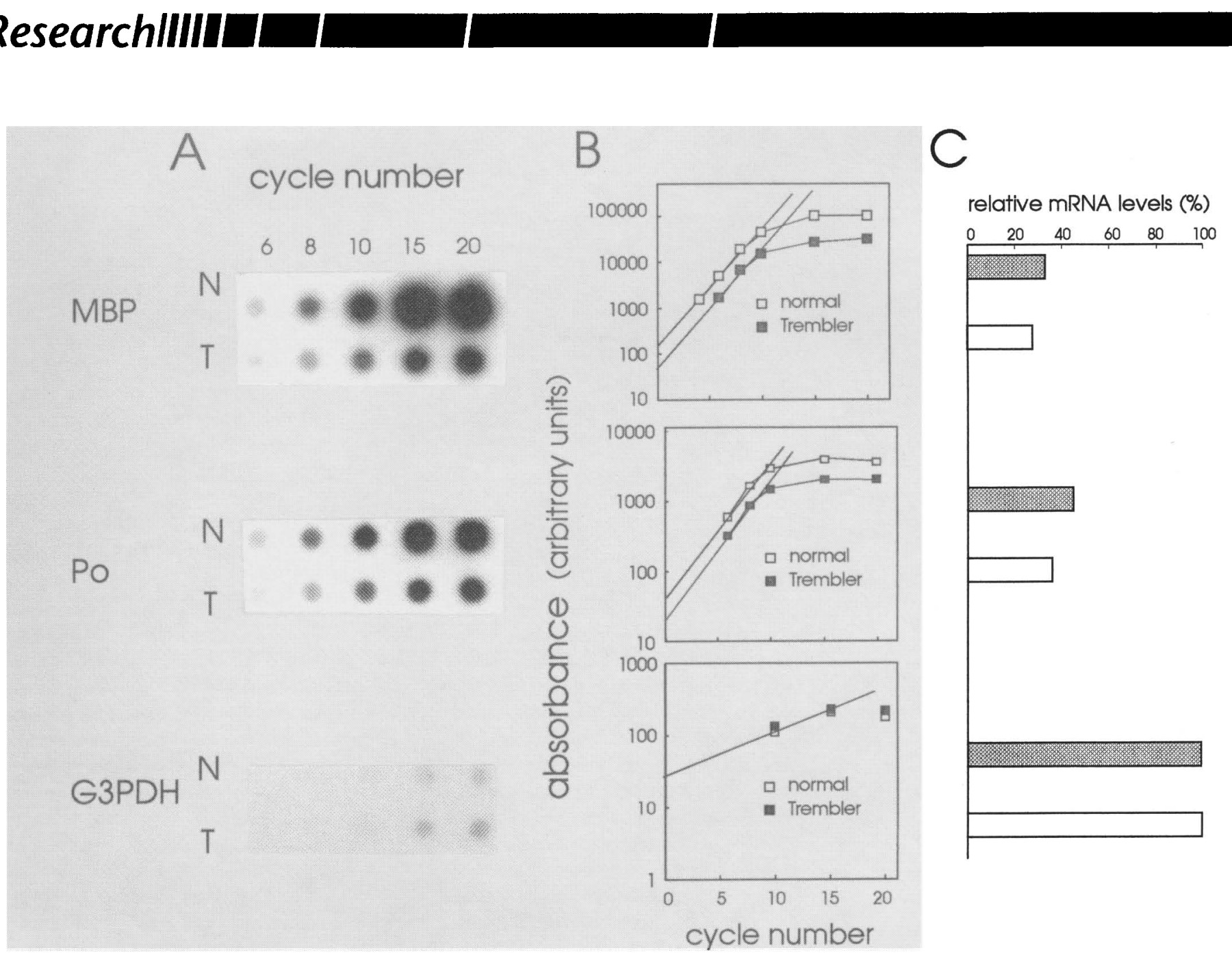

FIGURE 5 Relative quantitation of mRNA in normal and trembler mice. Total RNA purified from a single sciatic nerve from normal and trembler mouse was processed as described. CDNAs were ligated to S/T linker and used for the amplification. Kinetics were carried out at second-round PCR. Aliquots were taken at cycles $4,6,8,10,15$, and 20 and dotted on Hybond $\mathrm{N}$ membrane (Amersham). The blot was then hybridized consecutively to MBP, Po, MAG, and G3PDH probes. $(A)$ Representative autoradiographs of dot blots obtained with the different probes; $(B)$ curves obtained for MAG, MBP, and Po after scanning blots in $A$ using a Samba 2005 image analyzer; $(C)$ comparison of the results of this paper with those of Bascles et al. ${ }^{(24)}$ (Shaded bar) RT-PCR; (open bar) Northern hybridization. These results are presented as the percentage of the maximal level of specific mRNA found at 8 postnatal days.

used as an internal standard in previous Northern analyses. ${ }^{(23,24)}$ G3PDH blots showed (Fig. 5A) that there is nearly no difference in DNA loading between the samples under study (normal and trembler). Kinetics corresponding to Po, MBP, and G3PDH probes are displayed in Figure 5B. Because, from the above results, one can expect that a given sequence is always amplified with the same efficiency, we systematically used parallel straight lines for extrapolations. The extrapolation (Fig. 5B) ratios between normal and trembler MBP, and Po mRNA levels were calculated and compared to the previous values given by hybridization experiments (Fig. 5C). Both approaches show that MBP and Po mRNA levels decrease three and two times, respectively. Figure 6 shows the results of five parallel experiments for MAG. Because of a low signal-to-noise ratio, the data are scattered. However, they indicate that the ratio of MAG expression in the two samples is close to 1 . This compares well to the 1.5 -fold decrease determined by Northern blot experiments.

It is noteworthy that this experiment addresses itself to various mRNAs abundance, as Po and MPB mRNAs are highly abundant and MAG mRNA is expressed at a much lower level.

\section{DISCUSSION}

Several protocols using RT-PCR for measuring the level of a given mRNA species in total RNA have been described in the literature. ${ }^{(1-13)}$ This type of assay leads to very high sensitivity, allowing the quantitation of very low abundance mRNA species in minute amounts of tissues. However, each sequence to be quantitated necessitates preliminary calibration studies and at least one or several amplification assays.

Alternatively, our procedure allows the quantitation of many mRNA species from the products of a single two-round amplification reaction. Other protocols using the amplification of populations of DNA or cDNA have been applied to the preparation and the screening of cDNA libraries. ${ }^{(16,17)}$ In these cases, the representation of the amplified products was checked and found to be reasonable. 


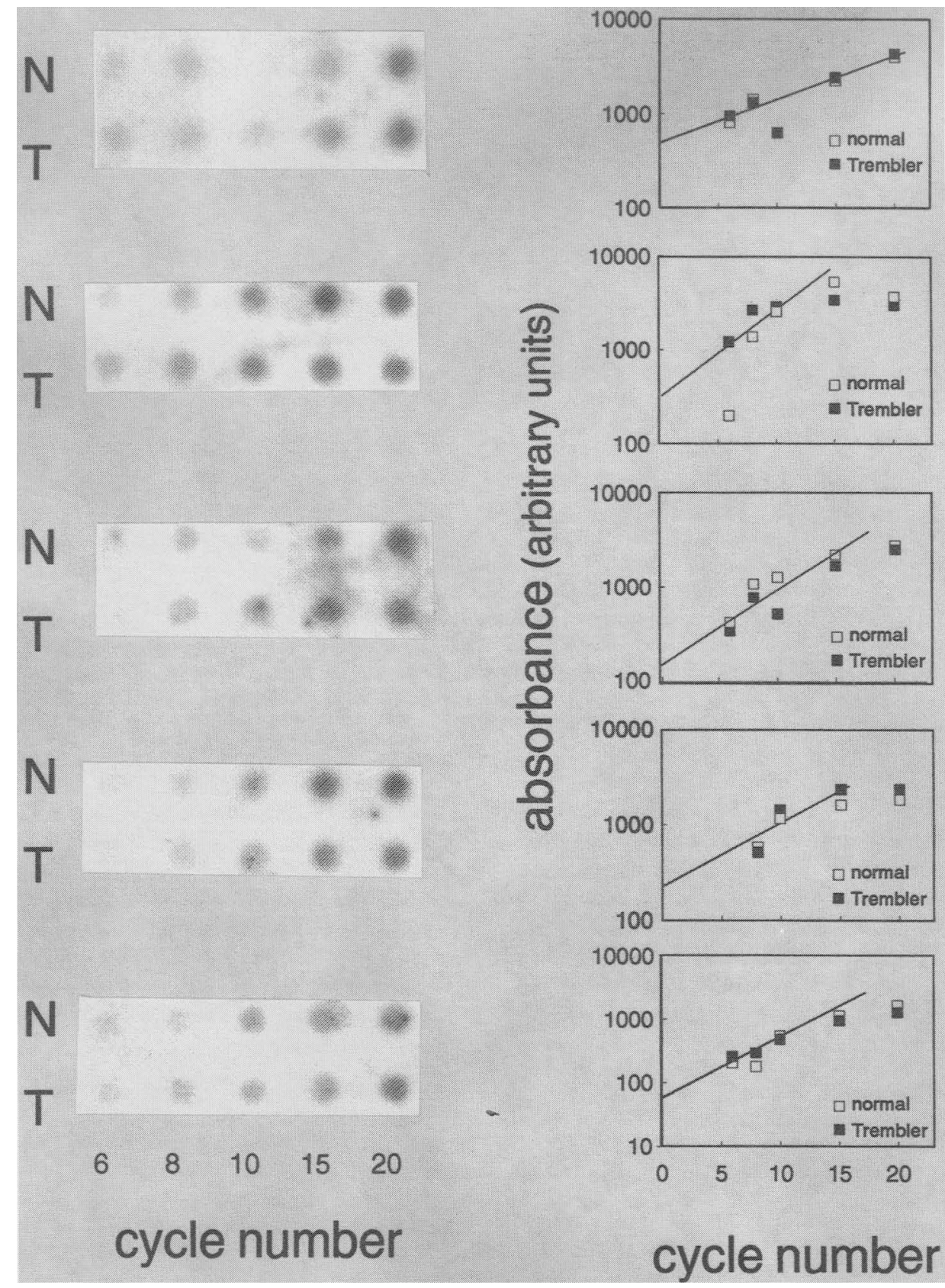

FIGURE 6 Comparison of MAG mRNA levels in normal and trembler mice. Five different kinetics of amplification were done as reported in Fig. 5. The dots were hybridized to the MAG CDNA probe. (Left) Autoradiographs; (right) results of the densitometric analysis.

However, our main purpose is not to compare a given species to another within the same population but to monitor relative changes of one or several mRNA species between different mRNA populations. In that case, it is necessary only that the ratio between amplification efficiencies of the sequences studied remains independent of the population considered. Two sets of controls suggest that this is the case. First in a model sys- necessary to see whether our procedure is reliable enough to detect variations less than twofold. While this approach cannot detect and quantitate very lowabundance mRNA species, only minute amounts of tissue are necessary and there is no need to know the sequence of the mRNA under study or to synthesize specific oligonucleotides to be used as primers, as a sequence-independent single primer is used in the amplification reaction. Nor is there any need to synthesize or clone an internal standard, as the method uses internal controls present in the RNA population, thus avoiding preliminary calibration constraints that are expensive and time consuming.

\section{ACKNOWLEDGMENTS}

We are grateful to P. Chambon, P. Bégueret, Dr. Lazzarini, Dr. Lemke, and Dr. J.L. Salzer for the gifts of hamster $\beta$-actin, $P$. anserina, mouse MBP, rat Po, and MAG probes, respectively, and to J.C. Gandar for the oligonucleotide synthesis. We thank Mrs. C. Sarger and D. Lacaze for their technical assistance. We are grateful to Drs. Bascles and Garbay for their help concerning the normal/trembler mouse system. This work was supported by the Centre National de la Recherche Scientifique, the University of Bordeaux II, the Conseil Regionnal d'Aquitaine, and the Association pour la Recherche Médicale Aquitaine. S.H. is a recipient of the Centre Culturel Hariri (Beirut, Lebanon) grant.

\section{REFERENCES}

1. Becker-André, M. and K. Hahlbrock. 1989. Absolute mRNA quantification using the polymerase chain reaction (PCR). A novel approach by a PCR aided transcript titration assay (PATTY). Nucleic Acids Res. 17: 9437-9446.

2. Wang, A.M., M.V. Doyle, and D.F. Mark. 1989. Quantitation of mRNA by the polymerase chain reaction. Proc. Natl. Acad. Sci. 86: $9717-9721$.

3. Gilliand, G., S. Perrin, K. Blanchard, and H.F. Bunn. 1990. Analysis of cytokine mRNA and DNA: Detection and quantitation by competitive polymerase chain reaction. Proc. Natl. Acad. Sci. 87: 27252729.

4. Chelly, J., D. Montarras, C. Pinset, Y. Berwald-Netter, J.-C. Kaplan, and A. Kahn. 1990. Quantitative estimation of minor mRNAs by cDNA-polymerase chain reac- 
tion. Application to dystrophin mRNA in cultured myogenic and brain cells. Eur. J. Biochem. 187: 691-698.

5. Syvänen, A.-C., K. Aalto-Setälä, L. Harju, K. Kontula, and H. Söderlund. 1990. A primer-guided nucleotide incorporation assay in the genotyping of apolipoprotein E. Genomics 8: 684-692.

6. Hoof, T., J.R. Riodan, and B. Tummler. 1991. Quantitation of mRNA by the kinetic polymerase chain reaction assay: $\mathrm{A}$ tool for monitoring P-glycoprotein gene expression. Anal. Biochem. 196: 161-169.

7. Ballagi, P.A. and K. Funa. 1991. Quantitative determination of mRNA phenotypes by the polymerase chain reaction. Anal. Biochem. 196: 89-94.

8. Robinson, M.O. and M.I. Simon. 1991. Determining transcript number using the polymerase chain reaction: Pgk-2, $\mathrm{mP} 2$ and PGK-2 transgene mRNA levels during spermatogenesis. Nucleic Acids Res. 19: 1557-1562.

9. Porcher, C., M.-C. Malange, C. Picat, and B. Granchamp. 1992. A simplified method for determination of specific DNA or RNA copy number using quantitative PCR and an automatic DNA segment analyser. Biotechniques 13: 106113.

10. Singer-Sam, J., J.M. Lebon, A. Dai, and A. Riggs. 1992. A sensitive, quantitative assay for measurement of allele-specific transcripts differing by a single nucleotide. PCR Methods Applic. 1: 160-163.

11. Pannetier, C., M. Cochet, S. Darche, and P. Kourilsky. 1992. A quantitative method for the titration of nucleic acids by enzymatic amplification (PCR) run to saturation. C.R. Acad. Sci., Serie III Sci. Vie 315: 271-277.

12. Platzer, C., G. Richter, K. Überla, W. Müller, H. Blöcker, T. Diamantstein, and T. Blankenstein. 1992. Analysis of cytokine mRNA levels in interleukin-4-transgenic mice by quantitative polymerase chain reaction. Eur. J. Immunol. 22: 11791184.

13. Pannetier, C., S. Delassus, S. Darche, C. Saucier, and P. Kourilsky. 1993. Quantitative titration of nucleic acids by enzymatic amplification reactions run to saturation. Nucleic Acids Res. 23: 577-583.

14. Ko, M.S.H., S.B.H. Ko, N. Takahashi, K. Nishiguchi, and K. Abe. 1990. Unbiased amplification of a highly complex mixture of DNA fragments by "lone-linker"tagged PCR. Nucleic Acids Res. 18: 42934294.

15. Reyes, G.R. and J.P. Kim. 1991. Sequenceindependent single-primer amplification (SISPA) of complex DNA populations. Mol. Cell. Probes 5: 473-481.

16. Brunet, J.-F., E. Shapiro, S.A. Foster, E.R. Kandel, and Y. lino. 1991. Identification of a peptide specific for Aplysia sensory neurons by PCR-based differential screen- ing. Science 252: 856-859.

17. Domec, C., B. Garbay, M. Fournier, and J. Bonnet. 1990. cDNA construction from small amounts of unfractionated RNA: Association of CDNA synthesis with polymerase chain reaction amplification. Anal. Biochem. 188: 422-426.

18. Chirgwin, J.M., A.E. Przybyla, R.J. MacDonald, and W.J. Rutter. 1979. Isolation of biologically active ribonucleic acid from sources enriched in ribonuclease. Biochemistry 18: 5294-5299.

19. Turcq, B., M. Denayrolles, and J. Bequeret. 1990. Isolation of the allelic incompatibility genes $\mathrm{S}$ and $\mathrm{S}$ of the fungus Podospora anserina. Curr. Genetics 17: 297-303.

20. Afar, D.E.H., R.M. Marius, J.L. Salzer, C.P. Stanners, P.E. Braun, and J.C. Bell. 1991. Cell adhesion properties of myelin-associated glycoprotein in L-cell fibroblast. $J$. Neurosci. Res. 29: 459-436.

21. Falconer, D.S. 1951. Two new mutants, "Trembler" and "Reeler" with neurological actions in the house mouse (Mus Muscul. L.). J. Genet. 50: 192-201.

22. Jacque, C., A. Delassalle, M. Raoul, and N. Baumann. 1983. Myelin basic protein deposition in the optic and sciatic nerves of dysmyelinating mutants Quacking Jimpy, Trembler, med and shiverer during development. I. Neurochem. 41: $1335-1340$.

23. Garbay, B., M. Fournier, M.L. Sallafranque, S. Muller, F. Boiron, A. Heape, C. Cassagne, and J. Bonnet. 1988. P0, MBP, histone and RNA levels in sciatic nerve: Postnatal accumulation studies in normal and trembler mice. Neurochem. Pathol. 8: 91-107.

24. Garbay, B., C. Domec, M. Fournier, and J. Bonnet. 1989. Developmental expression of the PO glycoprotein and basic protein mRNAs in normal and Trembler mutant mice. J. Neurochem. 53: 907-911.

25. Bascles, L., J. Bonnet, and B. Garbay. 1992. Expression of the PMP-22 gene trembler mutant mice: Comparison with the other myelin protein genes. Dev. Neurosci. 14: $336-341$.

Received July 28, 1994; accepted in revised form September 12, 1994. 


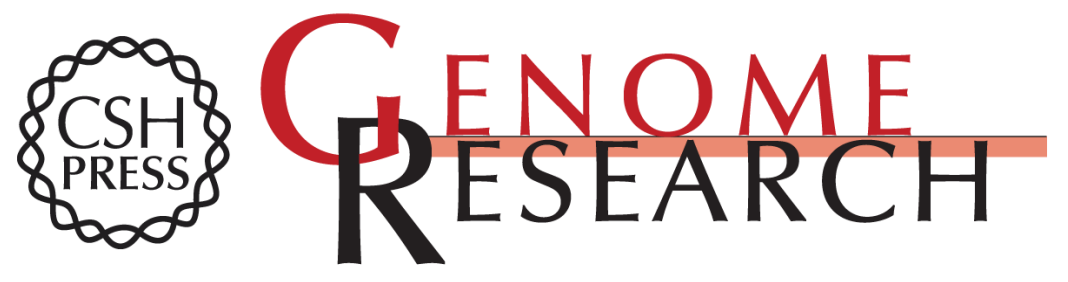

\section{Quantitation of mRNA species by RT-PCR on total mRNA population.}

S Hamoui, J P Benedetto, M Garret, et al.

Genome Res. 1994 4: 160-166

References This article cites 25 articles, 3 of which can be accessed free at: http://genome.cshlp.org/content/4/3/160.full.html\#ref-list-1

\section{License}

Email Alerting

Receive free email alerts when new articles cite this article - sign up in the box at the Service top right corner of the article or click here.

\section{Affordable, Accurate Sequencing.}

To subscribe to Genome Research go to: https://genome.cshlp.org/subscriptions 